\title{
Indexation of Fixed-Income Portfolios to the IMA-B
}

\author{
Emilio Ricardo Carvalhais ${ }^{\dagger}$ \\ Bank of Brazil \\ Antonio Marcos Duarte Júnior ${ }^{\Omega}$ \\ Ibmec Business School
}

\begin{abstract}
This study considers the problem of indexing fixed-income portfolios to the ANBIMA Market Index - Series B (IMA-B), composed of Brazilian National Treasury Notes - Series B (NTNBs). We propose a mathematical model that minimizes the deviations of the returns of the chosen portfolio in relation to the returns of the index's theoretical portfolio. The resulting model is a mathematical programming problem with convex objective function, linear constraints and free and non-negative integer variables. Five numerical examples with real data are presented to illustrate the model's practical use. The results obtained from the fits are analyzed together with data for funds indexed to the IMA-B existing in the Brazilian financial market. The proposed method resulted in fits with optimal control of the tracking errors of the indexed portfolio.
\end{abstract}

Keywords: IMA-B. Passive management. Indexation. NTN-B. Fixed income.

*Author for correspondence:

. M.Sc. from Ibmec Business School/RJ Institution: Division Manager, Banco do Brasil Gestão de Recursos DTVM S/A.

Address: Praça XV de Novembro, Rio de Janeiro, RJ - Brazil

E-mail: ecarvalhais@bb.com.br Telephone: (21) 3808-7531.
$\Omega$ Ph.D. in Applied Mathematics, Princeton University, USA. Institution: Professor at Ibmec Business School/RJ and Rio de Janeiro State University (UERJ).

Address: Avenida Presidente Wilson, Rio de Janeiro, RJ - Brazil

E-mail: antoniomarcosdj@uerj.br

Telephone: (21)4503400.

Note from the Editor: This article was accepted by Emerson Mainardes 


\section{INTRODUCTION}

he Brazilian Association of Financial and Capital Market Entities (Associação Brasileira das Entidades dos Mercados Financeiros e de Capitais - ANBIMA) has structured a family of indexes for use as benchmarks by investors in the Brazilian fixed income market (ANBIMA, 2010a).

The main fixed-income index proposed by ANBIMA is the ANBIMA Market Index - General (IMA-General), which can be decomposed into four other indexes:

1. IMA-B, launched in 2005, composed of National Treasury Notes - Series B (NTN-Bs), indexed to the Consumer Price Index (IPCA).

2. IMA-C, launched in 2005, composed of National Treasury Notes - Series C (NTN-Cs), indexed to the General Market Price Index (IGP-M).

3. IRF-M, launched in 2000, composed of National Treasury Letters (LTNs) and National Treasury Notes - Series F (NTN-Fs), representing fixed-rate bonds.

4. IMA-S, launched in 2005, composed of Treasury Financial Letters (LFTs), representing bonds indexed to the Central Bank's reference rate (SELIC).

According to ANDIMA (2009), the participation of the IMA-B in the IMA-General was $3 \%$ in 2005 , a percentage that increased to $25 \%$ in the first half of 2010 (ANBIMA, 2010b) and reached $32 \%$ at the end of 2013 (ANBIMA, 2014).

In 2009, the total number of investment funds that used the IMA-General or one of its components as the benchmark portfolio was 35 (Samuel, 2009). The expectation was for fast growth of the use of the IMA indexes as references, as an alternative to the yields on interbank certificates of deposit (CDIs), especially in the case of pension funds and insurance company portfolios due to the long-term characteristics of their liabilities. One year later, in 2010, this number had risen to 93, of which 49 specifically adopted the IMA-B (ANBIMA, $2010 \mathrm{~b}$ ). At the end of 2013, the number of funds using the IMA-B as the benchmark index had risen to 143, with assets under management of nearly R $\$ 40$ billion (ANBIMA, 2014).

Recent changes in the rules on pension funds also have increased the importance of the IMA indexes:

1. National Monetary Council (CMN) Resolution 3,456/2007 permitted using the IMA indexes as parameters for setting performance fees. 
2. CMN Resolution 3,790/2009, and later CMN Resolution 3,922/2012, allowed fixed-income investments to have as "yield parameter one of the IMA indexes, or the composition of more than one of them."

The IMA-B is composed of NTN-Bs, which are papers indexed to the IPCA plus interest of $6 \%$ a year, along with a premium/discount, defined at the moment of trading. Of all federal public debt papers at the end of $2009,25 \%$ of the securities were tied to the IPCA (i.e., the NTN-B yield) according to the National Treasury Secretariat (BRASIL, 2009), a percentage that exceeded 30\% at the end of 2013 (BRASIL, 2013).

According to Silva, Carvalho \& Garrido (2009), the participation of pension funds in the market for NTN-Bs has increased in the past decade because of their need for long-term securities. In turn, according to Carvalho \& Morais (2009), the main buyers of NTN-Bs are pension funds and insurers, seeking to match the maturities of their assets and liabilities. As a consequence of the interest in NTN-Bs, demand has naturally increased in the financial market for investment funds that adopt the IMA-B as the benchmark portfolio.

The theme of this article is directly related to the best way to manage investment portfolios (CREMERS; PETAJISTO, 2009; FABOZZI; MARKOWITZ, 2011; FAMA; FRENCH, 2010; FERRI, 2007; PETAJISTO, 2011): actively or passively? While active portfolio managers respond to market expectations to try to obtain risk-adjusted returns that are greater than those of competitors and/or benchmark portfolios, passive managers do not respond to changes in market expectations (LARSEN; RESNICK, 1998; MAGGIN et al., 2007; VOLPERT, 2000).

Indexation is a form of passive management defined as structuring portfolios for the purpose of obtaining a return equal to some benchmark portfolio (BUCKLEY; KORN, 1998; COLEMAN; LI; HENNIGER; 2006; FRINO; GALLAGHER, 2001; FUSCO et al., 2007; GUASTAROBA; SPERANZA, 2012; JANSEN; VAN DIJK, 2002). The indexation of portfolios arose in the American stock market in the 1970s (CFA Institute, 2009), and in Brazil it was first used for a mutual fund offering in the 1990s (Duarte, 1997).

The growing interest in indexation of portfolios can be illustrated by three examples:

1. Reilly \& Kao (1992) showed that the evolution of the market for bond index funds in the United States skyrocketed from US\$ 3 billion in 1984 to over US\$ 80 billion in 1991. 
2. Nine years later, in 2010, the total value of assets invested in index funds was US\$ 1 trillion, of which 20\% was invested in fixed-income index funds, with institutional investors (mainly pension funds and insurance companies) being the main customers (Investment Company Institute, 2011).

3. At the end of 2012, the net assets invested in index funds in the United States had surpassed US\$ 1.3 trillion (Investment Company Institute, 2013).

Our objective here is to propose a method to enable managers in the Brazilian fixedincome market to index their portfolios to the IMA-B using only NTN-Bs as assets. Although other articles have described the indexation of portfolios to stock market indexes in Brazil (CALDEIRA; PORTUGAL, 2010; DUARTE, 1997; SANFINS; DUARTE, 2014; SANT'ANNA; FILOMENA; BORENSTEIN, 2014), we did not find any article proposing a method for indexing portfolios to some Brazilian fixed-income index.

We believe this proposal will facilitate the process of managing funds that track the IMA-B by permitting better management of the relative market risk present in the structuring and management of indexed portfolios, minimizing the operating costs (brokerage and other fees), controlling the deviations in relation to the benchmark index (the IMA-B) and reducing the time spent structuring end executing fixed-income indexed portfolios. The results can thus be applied in practice immediately in the growing investment fund industry in Brazil.

The proposed method is based on a mathematical programming model (CORNUEJOLS; TUTUNCU, 2007) that allows the manger to minimize any loss function. These loss functions are based on the Macaulay duration (MD), permitting the manager to control how much the duration (FABOZZI, 1999) of the indexed portfolio can deviate from the duration of the theoretical portfolio composed of IMA-Bs according to different market scenarios. We performed simulations with four loss functions for purposes of numerical illustration. The resulting model is a mathematical programming problem with a convex objective function, linear constraints and free and non-negative integer variables (TAHA, 2008).

Although our specific interest here is indexation to the IMA-B, to a great extent the method presented can be adapted to indexation of portfolios to the IMA-C, with the manager using NTN-Cs for this purpose, or to the IRF-M, using LTNs and NTN-Fs.

We should note that exchange traded funds (ETFs) already exist in Brazil, but only for the equity market (BLACKROCK, 2013; BM\&FBOVESPA, 2013; BNDES, 2004). The use 
of ETFs for indexation in the international arena is growing, as illustrated by Alexander \& Barbosa (2008), Amenc \& Goltz (2009), Blitz, Huij \& Swinkels (2012), Bruce (2009), Bruce \& Fuhr (2012), Harper, Madura \& Schnusenberg (2006), Kostovetsky (2003) and Rompotis (2009). For the Brazilian case, this is depicted by Matos, Iquiapaza \& Ferreira (2014) and Sanfins \& Duarte (2014).

Although the trend in financial markets is indexation of portfolios with use of ETFs, in the specific case of the Brazilian fixed-income market, since there are no ETFs available, at present it is necessary to use the assets that compose the index of interest to structure indextracking portfolios. It is important to mention that the method presented in this article can be used directly to structure ETFs tied to the IMA-B, this being a major contribution of our study.

In the next section we describe the method used to index portfolios to the IMA-B, only employing NTN-Bs, starting from rigorous modeling of the resulting mathematical programming problem. The third section presents the results of five simulated studies with real data from the Brazilian financial market. The fourth section concludes the work and suggests some avenues for future research on the theme of indexation of fixed-income portfolios in Brazil.

\section{METHOD FOR INDEXING TO THE IMA-B}

We propose a method for indexation to the IMA-B structured in five steps:

1. Analysis of the theoretical portfolio of the IMA-B

2. Selection of the technique for passive management

3. Determination of the indexed portfolio

4. Generation of scenarios for the IPCA term structure

5. Structuring the portfolio

In the rest of this section we describe the five steps individually.

\subsection{ANALYSIS OF THE THEORETICAL PORTFOLIO OF THE IMA-B}

The first step for the indexation is to understand the composition of the theoretical portfolio of the IMA-B at the desired indexation moment. This theoretical portfolio can be visualized at the website of ANBIMA. Its composition is announced three days in advance for the next period (which always starts on the first business day after the $15^{\text {th }}$ of each month). The weights of the average maturities in the IMA-B correspond to the percentages by market 
value of each bond issue's maturity in relation to the total value of the NTN-Bs traded in the financial market.

As an illustration, Table 1 presents the composition (percentage) of the theoretical IMAB portfolio announced on December 15, 2010 for the period from December 16, 2010 to January 17, 2011. There were 15 NTN-B issues available for indexation of the portfolio to the IMA-B. For example, the NTN-B issue maturing on August 15, 2014 accounted for 3.63\% of the total market value of all NTN-Bs available for investment, while the issue maturing on August 5, 2016 accounted for $0.26 \%$ of the total value. The level of the IMA-B on December 15,2010 closed at 2361.30 .

Table 1 also presents the MD and Value-at-Risk (JORION, 2006) for all the NTN-B issues composing the IMA-B. For example, the issue maturing on May 15, 2040 had a MD of approximately 3,966 business days at market closing on December 15, 2010 and Value-atRisk of $-0.7342 \%$.

Table 1 - Theoretical Portfolio of the IMA-B on December 15, 2010

\begin{tabular}{cccc}
$\begin{array}{c}\text { Maturity } \\
\text { [dd/mm/yyyd }\end{array}$ & Weight & $\begin{array}{c}\text { Macaulay Duration } \\
\text { (business days) }\end{array}$ & $\begin{array}{c}\text { Value-at-Risk } \\
\text { (95\%, 1 year) }\end{array}$ \\
\hline $15 / 05 / 2011$ & $10.10 \%$ & 92.99 & $-0.0238 \%$ \\
$15 / 11 / 2011$ & $3.37 \%$ & 216.34 & $-0.0639 \%$ \\
$15 / 08 / 2012$ & $9.61 \%$ & 388.68 & $-0.1008 \%$ \\
$15 / 05 / 2013$ & $13.09 \%$ & 559.99 & $-0.1486 \%$ \\
$15 / 08 / 2014$ & $3.63 \%$ & 816.00 & $-0.2108 \%$ \\
$15 / 05 / 2015$ & $3.63 \%$ & 977.89 & $-0.2663 \%$ \\
$15 / 08 / 2016$ & $0.26 \%$ & 1198.23 & $-0.3172 \%$ \\
$15 / 05 / 2017$ & $8.13 \%$ & 1348.73 & $-0.3308 \%$ \\
$15 / 08 / 2020$ & $5.19 \%$ & 1844.08 & $-0.4500 \%$ \\
$15 / 08 / 2024$ & $7.63 \%$ & 2367.99 & $-0.4288 \%$ \\
$15 / 08 / 2030$ & $1.01 \%$ & 2976.75 & $-0.5332 \%$ \\
$15 / 05 / 2035$ & $7.26 \%$ & 3410.37 & $-0.6924 \%$ \\
$15 / 08 / 2040$ & $1.34 \%$ & 3699.11 & $-0.7342 \%$ \\
$15 / 05 / 2045$ & $13.58 \%$ & 4041.30 & $-0.7510 \%$ \\
$15 / 08 / 2050$ & $3.12 \%$ & 4149.10 & $-0.8234 \%$ \\
IMA-B & & 1675.55 & $-0.2889 \%$ \\
\hline
\end{tabular}

Source: Authors, with data from ANBIMA.

Two limitations of a practical nature cannot be ignored by managers regarding the indexation of portfolios to the IMA-B with NTN-Bs:

1. The National Treasury does not offer NTN-Bs with all maturities simultaneously in its auctions (i.e., in the primary market). Therefore, it is necessary to go to the secondary market to acquire assets, in which the bonds are generally traded in lots of 10,000 units. Furthermore, not all assets are necessarily tradable on a given day (there may not be any buyers, sellers or both for a determined NTN-B issue on a particular day), with the more liquid ones generally being those with shorter maturities. For example, at the end of 
2010, the average daily number of NTN-Bs with maturity on May 15, 2013 was around 170,000, while the corresponding figure for those maturing on May 15, 2045 was only 35,000 . For indexation of the portfolios to the IMA-B, we only use trades in lots (i.e., 10,000 units for purchase or sale), given that the costs related to fractioned lots can be substantially higher in the market due to questions of illiquidity.

2. With the price of a NTN-B at the end of 2010 hovering in the range of R\$ 2,000.00, the value of a lot (for purchase or sale) was approximately $\mathrm{R} \$ 20$ million. Therefore, to purchase a single lot of the bond issues with each of the 15 maturities in the secondary market would have required about R\$300 million. This requires the need to consider using bonds with fewer maturity dates than the 15 possible ones to index portfolios with small net asset values. Naturally for portfolios with high net assets (billions of reais), the possibility of buying lots with all maturities can be considered. For example, among the investment funds (active and passive) offered in the Brazilian financial market at the end of 2010 that used the IMA-B as benchmark index, only seven had more than R $\$ 1$ billion in net assets according to figures from the Brazilian Securities Commission (Comissão de Valores Mobiliários - CVM). In approaching the problem of indexing portfolios to the IMA-B, our proposed model is flexible in determining the number of maturities to be used, which can be much fewer than the total number available. In other words, this proposal allows managers to freely choose how many maturities they want to use to index their portfolios to the IMA-B.

\subsection{SELECTION OF TECHNIQUE FOR PASSIVE MANAGEMENT}

According to Fabozzi \& Markowitz (2011), the two most widely used possibilities for passive management of fixed-income portfolios are:

1. Buy-and-hold, when the manager buys fixed-income assets and always keeps them until maturity, reinvesting all the proceeds received in new (fixed income) assets, which are also held to maturity.

2. Indexation, when the manager tries to obtain performance equal to that of a chosen benchmark portfolio (usually a market index like the IMA-B). This is the possibility we address in this article.

In the specific case of indexation, the three most widely used techniques for passive portfolio management (BARRO; CANESTRELLI, 2009; CANAKGOZ; BEASLEY, 2009; GAIVORONSKI; KRYLOV; VAN DER WIJST, 2005; KRINK; MITTNIK; PATERLINI, 2009; YAO; ZHANG; ZHOU, 2006) are: 
1. Total replication, when there is purchase of exactly the same assets as contained in the theoretical benchmark portfolio, in the same proportion. As a positive point, this technique presents tracking error of zero in theory, although in practice there are very high operating costs (brokerage and other fees), since it requires continuous balancing of the portfolio any time there is a change in the composition of the benchmark portfolio or when payouts are received (e.g., twice-yearly interest).

2. Sampling replication, when some of the bonds that compose the benchmark portfolio are purchased, with the remaining amounts not invested in those assets being redistributed proportionally among those purchased. This technique has a lower operating cost than the previous one, but does not allow adequate control of the tracking errors, which can be high.

3. Minimization of mismatch, when a function that measures the deviations of the portfolio's structure in relation to the chosen benchmark portfolio is minimized. In this case, it is possible to use a smaller number of assets than contained in the benchmark portfolio, reducing the operating costs, with better control of tracking errors by the manager than in the case of sampling. This is the possibility we cover here, with the mismatch control measure being based on the MD. In other words, we seek to control the mismatch between the benchmark portfolio (IMA-B) and the indexed portfolio by minimizing the differences between the durations of the two portfolios for different scenarios generated for the evolution of the IPCA term structure. Below we present the mathematical formulation of the resulting optimization problem.

\subsection{DETERMINATION OF THE INDEXED PORTFOLIO}

Consider the problem of indexation in which there are $n+\mathbf{1}$ assets available for investment:

1. There are $n$ different NTN-B maturities available for investment. In numerical terms, $n=15$, as indicated in Table 1 .

2. A repo transaction is available (to play the role of "cash"), denoted as asset $n+1$.

For the $n$ available NTN-Bs, the amount invested in R\$, denoted by $X_{j}$, is obtained from:

$$
X_{j}=p_{j}^{h} \times l_{j} \times N_{j} \quad \forall j=1,2, \ldots, n
$$


Where:

1. The marked-to-the market price (in R $\$$ ) of NTN-B $i$ is denoted by $p_{j}^{\boldsymbol{h}}$.

2. The lot traded of NTN-B $i$ is denoted by $l_{j}$. In numerical examples, we adopt $l_{j}=10,000 \forall j=1,2, \ldots, n$.

3. The number of lots purchased of NTN-B $i$ is denoted by $N_{j}$, with $N_{j} \in\{0,1,2, \ldots\} \forall j=1,2, \ldots, n$.

It can be seen from equation (1) that $X_{j} \geq 0 \forall j=1,2, \ldots, n$.

We assume that the total amount for investment (in $\mathrm{R} \$$ ) is equal to $c$, with the necessary introduction of the constraint:

$$
c=\sum_{j=1}^{n+1} X_{j}
$$

where $X_{n+1}$ denotes the investment in repo transactions.

We also impose two restrictions related to the illiquidity of the $n+\mathbf{1}$ assets available for investment:

1. To minimize the problems of illiquidity at the time of future balancing of the indexed portfolio, we impose that:

$$
N_{j} \leq \gamma \times b_{j} \quad \forall j=1,2, \ldots, n
$$

where $b_{j}$ is the number of lots available for purchase in the entire NTN-B market and $\gamma$ denotes the maximum percentage of the market that can be held in the portfolio by the manager. For example, in the first numerical exercise, we use $\gamma=0,2 \%$.

2. Also to avoid illiquidity problems when investors redeem their shares in the fund, we impose the constraint:

$$
X_{n+1} \geq \alpha \times c,
$$

where $\alpha$ denotes the minimum percentage (of the total invested) that must be held as "cash" to cover redemption demands quickly. For example, in the first numerical exercise we use $\alpha=1 \%$.

We assume that $m$ scenarios are generated (equally probable) to calculate the returns of the $n$ NTN-Bs available for investment. We denote the price (marked to the market) and MD 
of NTN-B $i$ according to scenario $i$ by $p_{i j}$ and $d_{i j}$, respectively, with $i=1,2, \ldots, m$ and $j=1,2, \ldots, n$. For the case of the repo transaction, its duration is one day (i.e., $\left.d_{i n+1}=1 \quad \forall i=1,2, \ldots, m\right)$.

We obtain the MD $D_{i}$ of the indexed portfolio for each scenario $i$ with the equation:

$$
c \times D_{i}=1 \times X_{n+\mathbf{1}}+\sum_{j=1}^{n} d_{i j} \times p_{i j} \times l_{j} \times N_{j} \quad \forall i=1,2, \ldots, m
$$

The MD is always positive, so $D_{i} \geq 0 \quad \forall i=1,2, \ldots, m$.

We denote the MD of the theoretical portfolio of the IMA-B for scenario $i$ as $d_{i}^{I}$.

Our aim here is to minimize the mismatch between the MD of the benchmark portfolio and that of the indexed portfolio for the set of $m$ scenarios generated for analysis. Since the sensitivity of the prices of fixed-income assets is directly proportional to their duration in case of small parallel movements of the term structure, the proposed minimization allows controlling the tracking error, and consequently controlling the market risks related to interest rates.

The deviations between the MD of the theoretical portfolio of the IMA-B and the indexed portfolio are denoted by $E_{i}$, defined by the relation:

$$
E_{i}=d_{i}^{I}-D_{i} \quad \forall i=1,2, \ldots, m
$$

Since it is not possible to guarantee that the errors will always be positive or negative, then $-\infty<E_{i}<+\infty \quad \forall i=1,2, \ldots, m$.

We denote the objective function of the problem as $L\left(E_{1}, E_{2}, \ldots, E_{m}\right)$. This function serves as a "loss function" or "error function", and our objective is always to minimize it. In this article we use four loss functions for purposes of numerical illustration:

1. Mean absolute error (MAE)

$$
L\left(E_{1}, E_{2}, \ldots, E_{m}\right)=\frac{1}{m} \times \sum_{i=1}^{m}\left|E_{i}\right|
$$

2. $\quad$ Mean squared error (MSE)

$$
L\left(E_{1}, E_{2}, \ldots, E_{m}\right)=\frac{1}{m} \times \sum_{i=1}^{m} E_{i}^{2}
$$

3. Maximum absolute error (MaxAE) 


$$
L\left(E_{1}, E_{2}, \ldots, E_{m}\right)=\text { máximo }\left\{\left|E_{1}\right|,\left|E_{\mathbf{2}}\right|, \ldots,\left|E_{m}\right|\right\}
$$

4. Median of absolute errors (MedAE)

$$
L\left(E_{1}, E_{2}, \ldots, E_{m}\right)=\text { mediana }\left\{\left|E_{\mathbf{1}}\right|,\left|E_{\mathbf{2}}\right|, \ldots,\left|E_{m}\right|\right\}
$$

The complete optimization model can be written in compact form as:

$$
\begin{gathered}
\text { Minimize } \\
\text { Subjected to: } \left.E_{1}, E_{2}, \ldots, E_{m}\right) \\
E_{i}=d_{i}^{I}-D_{i} \quad \forall i=1,2, \ldots, m \\
c \times D_{i}=1 \times X_{n+1}+\sum_{j=1}^{n} d_{i j} \times p_{i j} \times l_{j} \times N_{j} \quad \forall i=1,2, \ldots, m \\
c=\sum_{j=1}^{n+1} X_{j} \\
X_{j}=p_{j}^{h} \times l_{j} \times N_{j} \quad \forall j=1,2, \ldots, n \\
N_{j} \leq \gamma \times b_{j} \quad \forall j=1,2, \ldots, n \\
X_{n+1} \geq \alpha \times c \\
N_{j} \in\{0,1,2, \ldots\} \forall j=1,2, \ldots, n \\
X_{j} \geq 0 \quad \forall j=1,2, \ldots, n+1 \\
D_{i} \geq 0 \quad \forall i=1,2, \ldots, m \\
-\infty<E_{i}<+\infty \quad \forall i=1,2, \ldots, m
\end{gathered}
$$

Based on (11), the resulting mathematical programming model contains:

1. A total of $n$ integer variables.

2. A total $n+m+\mathbf{1}$ non-negative variables.

3. A total of $m$ free variables.

4. A total of $n+2 m+1$ linear equality constraints.

5. A total of $n+\mathbf{1}$ linear inequality constraints.

\subsection{GENERATION OF SCENARIOS FOR THE IPCA TERM STRUCTURE}

A highly demanding step from the operational standpoint when using model (11) to index portfolios is related to the generation of the ${ }^{m}$ scenarios for the IPCA term structure.

The process of generating these scenarios is composed of five steps:

1. Obtain the IPCA term structure at market closing of the previous day.

2. After obtaining this IPCA term structure (prior day's closing), the manager can mark to the market all the NTN-Bs available for investment, and in this way obtain the values of the parameters $p_{j}^{\boldsymbol{h}}$ in model (11).

3. Now, given the term structure at market closing on the previous day, and given the balancing horizon (e.g., daily, as in the case of the numerical examples presented below), 
the manager must simulate $m$ possible realizations - i.e., scenarios - for the evolution of the IPCA term structure in this time period.

4. Next, for each term structure simulated, the manager must calculate the price (marked to the market) and MD for each maturity date of the NTN-Bs available for investment. Therefore, the manager will have generated the values for the parameters $p_{i j}$ and

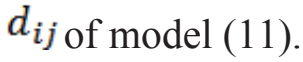

5. Finally, the manager must calculate the expected MD for each portfolio of the IMA-B according to each scenario generated, and in this way obtain the values of the parameters $d_{i}^{I}$ of model (11).

Here the process of estimating and simulating the IPCA term structures, as well as the marking to the market of all the NTN-Bs, is based on the method described in Banco do Brasil (2006, 2010). The method used by Banco do Brasil is based on the historical simulation proposed for calculating the Value-at-Risk of fixed-income portfolios (JORION, 2006).

\subsection{STRUCTURING THE PORTFOLIO}

Once the necessary parameters have been obtained, the manger must resolve/optimize model (11) for the preferred loss function $L\left(E_{1}, E_{2}, \ldots, E_{m}\right)$.

At the end, the optimal values obtained for the variables $N_{1}, N_{2}, \ldots, N_{n}$ will indicate the amounts (in numbers of lots) to be acquired for the best indexation to the IMA-B portfolio.

\section{NUMERICAL EXAMPLES}

In this section we present five simulated studies to illustrate model (11) with real data.

\subsection{FIRST SIMULATED STUDY}

The following parameters were used in this first case:

1. The total available for investment was set at $\mathrm{R} \$ 400$ million (i.e., $c=40000000 \mathrm{o}$ ). We chose this amount based on the median net asset values of the funds indexed to the IMA-B listed by the CVM at the end of 2010. This amount is changed in the second simulated study.

2. The minimum amount of cash was set at $\mathrm{R} \$ 4$ million (i.e., $\alpha=1 \%$ ). This amount is changed in the third simulation exercise.

3. The maximum number of lots of any maturity of NTN-Bs was set at $0,2 \%$ of the total amount available in the market, for questions of liquidity (i.e., $\gamma=0,2 \%$ ). This amount is altered in the forth simulated study. 
Table 2 summarizes the allocations in the indexed portfolios for each of the four loss functions suggested in the previous section. For example, for the loss function MaxAE, it can be seen that the indexation is done with a lot of NTN-Bs maturing on May 15, 2011, two lots maturing on May 15, 2013, and so forth until a lot with maturity on August 15, 2050, and finally $\mathrm{R} \$ 15,129,841$ in cash. In percentage terms (in relation to the $\mathrm{R} \$ 400$ million available), the allocation in NTN-Bs with maturity on May 15, 2011 corresponds to $5.00 \%$, in NTN-Bs with maturity on May 15, 2013 to $9.90 \%$, and so on until $5.40 \%$ corresponding to maturity on August 15, 2050, and 3.78\% in cash.

Table 2 - Portfolios Indexed to the IMA-B in the First Simulation

\begin{tabular}{|c|c|c|c|c|c|c|c|c|c|}
\hline \multirow{2}{*}{$\begin{array}{c}\text { Maturity } \\
{[\mathrm{dd} / \mathrm{mm} / \mathbf{y y y y}]}\end{array}$} & \multirow[t]{2}{*}{ Weight } & \multicolumn{2}{|c|}{ MAE } & \multicolumn{2}{|l|}{ MSE } & \multicolumn{2}{|l|}{ MaxAE } & \multicolumn{2}{|c|}{ MedAE } \\
\hline & & Lots / Value & $\%$ & Lots / Value & $\%$ & Lots / Value & $\%$ & Lots / Value & $\%$ \\
\hline $15 / 05 / 2011$ & $10.10 \%$ & 2 & 10.01 & & & 1 & 5.00 & & \\
\hline $15 / 11 / 2011$ & $3.37 \%$ & & & & & & & & \\
\hline $15 / 08 / 2012$ & $9.61 \%$ & 1 & 5.03 & 1 & 5.03 & & & 1 & 5.03 \\
\hline $15 / 05 / 2013$ & $13.09 \%$ & & & 2 & 9.90 & 2 & 9.90 & & \\
\hline $15 / 08 / 2014$ & $3.63 \%$ & & & 1 & 5.01 & & & 1 & 5.01 \\
\hline $15 / 05 / 2015$ & $3.63 \%$ & 5 & 24.76 & 4 & 19.81 & 5 & 24.76 & 5 & 24.76 \\
\hline $15 / 08 / 2016$ & $0.26 \%$ & & & & & & & & \\
\hline $15 / 05 / 2017$ & $8.13 \%$ & 3 & 14.99 & 3 & 14.99 & 3 & 14.99 & 3 & 14.99 \\
\hline $15 / 08 / 2020$ & $5.19 \%$ & 2 & 10.17 & 2 & 10.17 & 2 & 10.17 & 2 & 10.17 \\
\hline $15 / 08 / 2024$ & $7.63 \%$ & 3 & 15.43 & 3 & 15.43 & 3 & 15.43 & 3 & 15.43 \\
\hline $15 / 08 / 2030$ & $1.01 \%$ & & & & & & & & \\
\hline $15 / 05 / 2035$ & $7.26 \%$ & & & 1 & 5.21 & 1 & 5.21 & 1 & 5.21 \\
\hline $15 / 08 / 2040$ & $1.34 \%$ & & & & & & & & \\
\hline $15 / 05 / 2045$ & $13.58 \%$ & 3 & 16.07 & 2 & 10.71 & 1 & 5.36 & 1 & 5.36 \\
\hline $15 / 08 / 2050$ & $3.12 \%$ & & & & & 1 & 5.40 & 1 & 5.40 \\
\hline Cash & & $\mathrm{R} \$ 14,200.180$ & 3.55 & $\mathrm{R} \$ 14,954.872$ & 3.74 & $\mathrm{R} \$ 15,129.841$ & 3.78 & $\mathrm{R} \$ 34,572.511$ & 8.64 \\
\hline
\end{tabular}

Source: Authors.

It can also be observed in Table 2 that the allocations in bonds with intermediate maturities (May 15, 2017, August 15, 2020 and August 15, 2024) were equal for the four loss functions. The greatest variations in the allocations in NTN-Bs occurred in the short-term and long-term positions, as in the case of the position in repo transactions for the loss function MedAE.

Table 3 presents some statistics for the duration and tracking errors of the four portfolios of Table 2, as well as for the three funds indexed to the IMA-B offered to the market that had the highest net asset values at the end of 2010. The statistics presented are:

1. The Value-at-Risk benchmark (B-VaR) for the tracking errors of each portfolio/fund in relation to the IMA-B (Duarte, 2005).

2. The difference (or deviation) of the MD calculated for each portfolio/fund in relation to the MD of the IMA-B at the close of trading on December 30, 2010.

3. The values $\beta$ and $R^{2}$ of the regression of the returns of each portfolio/fund (denoted $r_{1}^{C}, r_{2}^{C}, \ldots, r_{126}^{C}$ ) against the returns of the IMA-B (denoted $r_{1}^{I}, r_{2}^{I}, \ldots, r_{126}^{I}$ ) when considering the daily returns of the previous six months (i.e., 120 business days), according to the linear regression model: 


$$
r_{l}^{C}=\alpha+\beta \times r_{l}^{I}+\epsilon_{l} \quad \forall l=1,2, \ldots, 126
$$

with estimation by ordinary least squares and errors assumed to be independent and equally distributed according to a distribution $N\left(0 ; \sigma^{2}\right)$.

Table 3 - Some Statistics Obtained for the First Simulation

\begin{tabular}{|c|c|c|c|c|c|}
\hline Cart. Ind. / Funds & Net Assets (approx.) & $\begin{array}{c}\text { B-VaR } \\
(95 \%, 1 \text { day })\end{array}$ & $\begin{array}{l}\text { Macaulay Dur. Dev. } \\
\text { (business days) }\end{array}$ & $\begin{array}{c}\text { Beta } \\
(\beta)\end{array}$ & $i h^{2}$ \\
\hline MAE & $\mathrm{R} \$ 400$ million & $-0.036 \%$ & -0.31 & 1.0377 & $99.41 \%$ \\
\hline MSE & $\mathrm{R} \$ 400$ million & $-0.048 \%$ & -0.35 & 1.0539 & $98.99 \%$ \\
\hline MaxAE & $\mathrm{R} \$ 400$ million & $-0.047 \%$ & -0.04 & 1.0515 & $99.03 \%$ \\
\hline MedAE & $\mathrm{R} \$ 400$ million & $-0.048 \%$ & 0.36 & 1.0519 & $98.92 \%$ \\
\hline Fund 1 & $\mathrm{R} \$ 482$ million & $-0.020 \%$ & -80 & 0.9629 & $99.91 \%$ \\
\hline Fund 2 & $\mathrm{R} \$ 4$ billion & $-0.072 \%$ & -283 & 0.8321 & $99.99 \%$ \\
\hline Fund 3 & $\mathrm{R} \$ 118$ million & $-0.053 \%$ & -53 & 0.9301 & $98.10 \%$ \\
\hline
\end{tabular}

Source: Authors

It can be seen in Table 3 that:

1. The B-VaR and deviations of the duration of the four indexed portfolios obtained with model (11) are at the same level, while the same cannot be said for the three market funds, especially Fund 2. For example, the deviations of the MD values of the indexed portfolios are lower than one business day, in contrast to the three market funds, in particular Fund 2, with a deviation of more than one year. Not coincidentally, Fund 2 has the highest value (in modulus) of $\mathrm{B}-\mathrm{VaR}$.

2. The $R^{2}$ values and analysis of the residuals indicate good fits for the linear regression model (12), which allows testing if the betas of the four portfolios and three funds differ from the expected value for indexed portfolios - i.e., 1.0 - at 5\% significance (DUARTE, 2005). It is not possible to reject the hypothesis of beta equal to 1.0 for the four portfolios, which should be interpreted as a positive indicator of indexation. The same does not occur for the three funds offered to the market, whose betas are all significantly different from 1.0 (in the three cases, lower than 1.0) at 5\% significance, suggesting deficient indexing.

Figure 1 presents box-plots for the tracking errors of the four portfolios in relation to the IMA-B for the scenarios employed in the optimization. The distributions are symmetric, with the one most concentrated around zero being that related to the loss function MAE. With respect to the magnitudes of the deviations, in the worst stress scenarios the tracking errors are lower than $0.09 \%$ (in modulus), which is a good result. 


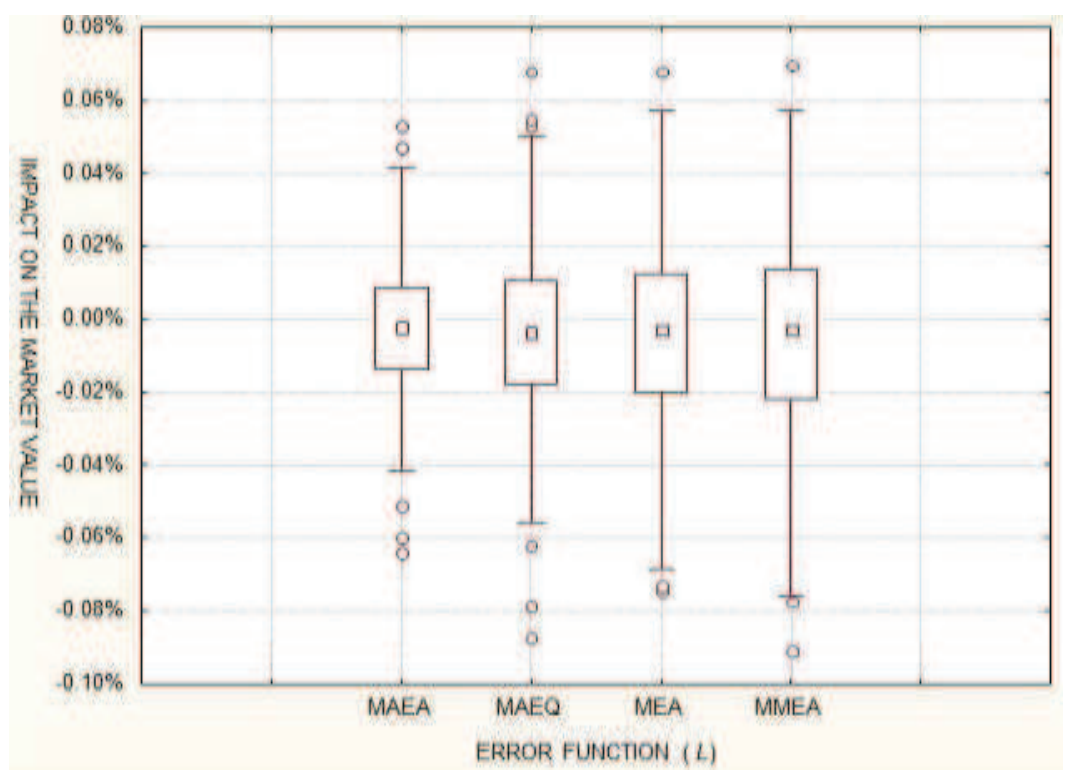

Figure 1 - Tracking Errors of the First Simulation

Figure 2 presents the deviations of the MD values for each of the four indexed portfolios. Even in the worst stress scenarios, the deviations do not exceed six business days (in absolute value), further evidence of the model's good fits (11).

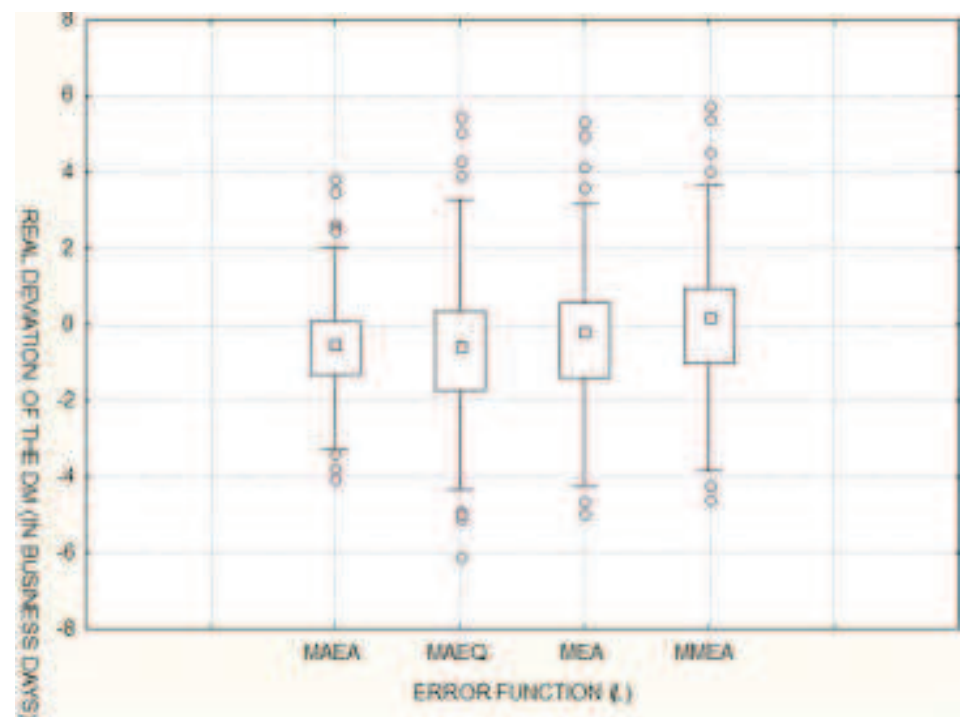

Figure 2 - Deviations of the Macaulay Duration of the First Simulation

From this first simulation exercise, we can observe that:

1. The use of the four loss functions did not result in appreciably different IMAB-indexed portfolios in terms of composition (Table 2) and performance (Table 3, Figure 1 and Figure 2).

2. When comparing the four indexed portfolios against the portfolios of the three largest funds offered to the Brazilian market indexed to the IMA-B, there was a substantial difference in terms of quality of the indexing (Table 3), with a big disadvantage for the last three. 
3. The tracking errors (Figure 1) and deviations of the MD (Figure 2) were within the desired parameters for an indexed portfolio, with deviations concentrated and symmetric about zero, and random values and signs (positive or negative) (Figure 3 ).

\subsection{SECOND SIMULATED STUDY}

In the second simulation exercise we illustrate the effect of portfolio size on the quality of the indexation. For that purpose, we reduced the amount available for investment by half, from $c=400000000$ to $c=200000000$. The parameters $\alpha$ and $\gamma$ are the same as in the first simulated study.

Table 4 presents the data for the four indexations obtained. A comparison between Table 4 and Table 2 reveals that:

1. There is more concentrated allocation (i.e., smaller number of maturity dates) in the case of Table 4, a direct consequence of the more restricted possibility for choosing bond issues because of the reduction of the cash available for investment.

2. Unlike in Table 2, in Table 4 there is lower concentration of investments in positions with intermediate maturities.

3. The four allocations in repo transactions are of the same order of magnitude in Table 4.

Table 4 - Portfolios Indexed to the IMA-B of the Second Simulation

\begin{tabular}{|c|c|c|c|c|c|c|c|c|c|}
\hline \multirow{2}{*}{$\begin{array}{c}\text { Maturity } \\
\text { [dd/mm/yyyy] }\end{array}$} & \multirow[t]{2}{*}{ Weight } & \multicolumn{2}{|c|}{ MAE } & \multicolumn{2}{|l|}{ MSE } & \multicolumn{2}{|l|}{ MaxAE } & \multicolumn{2}{|l|}{ MedAE } \\
\hline & & Lots / Value & $\%$ & Lots / Value & $\%$ & Lots / Value & $\%$ & Lots / Value & $\%$ \\
\hline 15/052011 & $10.10 \%$ & & & & & & & & \\
\hline $15 / 11 / 2011$ & $3.37 \%$ & & & & & 1 & 9.95 & & \\
\hline $15 / 08 / 2012$ & $9.61 \%$ & & & & & & & 1 & 10.07 \\
\hline $15 / 05 / 2013$ & $13.09 \%$ & 2 & 19.81 & & & & & & \\
\hline $15 / 08 / 2014$ & $3.63 \%$ & & & 1 & 10.02 & & & 1 & 10.02 \\
\hline $15 / 05 / 2015$ & $3.63 \%$ & & & 3 & 29.71 & 2 & 19.81 & 1 & 9.90 \\
\hline $15 / 08 / 2016$ & $0.26 \%$ & & & & & & & & \\
\hline $15 / 05 / 2017$ & $8.13 \%$ & 2 & 19.98 & 2 & 19.98 & & & 3 & 29.97 \\
\hline $15 / 08 / 2020$ & $5.19 \%$ & 2 & 20.33 & & & 2 & 20.33 & 1 & 10.17 \\
\hline $15 / 08 / 2024$ & $7.63 \%$ & 2 & 20.57 & 1 & 10.28 & 3 & 30.85 & & \\
\hline $15 / 08 / 2030$ & $1.01 \%$ & & & & & & & & \\
\hline $15 / 05 / 2035$ & $7.26 \%$ & & & 1 & 10.42 & 1 & 10.42 & & \\
\hline $15 / 08 / 2040$ & $1.34 \%$ & & & & & & & & \\
\hline $15 / 05 / 2045$ & $13.58 \%$ & 1 & 10.71 & 1 & 10.71 & & & 2 & 21.42 \\
\hline $15 / 08 / 2050$ & $3.12 \%$ & & & & & & & & \\
\hline Cash & & $\mathrm{R} \$ 17,197.479$ & 8.60 & $\mathrm{R} \$ 17,720.175$ & 8.86 & $\mathrm{R} \$ 17,259.083$ & 8.63 & $\mathrm{R} \$ 16,882.496$ & 8.44 \\
\hline
\end{tabular}

The statistics of the new portfolios, as shown in Table 5, when compared with those in

Table 3, indicate a small deterioration of the quality of the indexation in two cases (MAE and MaxAE), and no relevant changes in the other two cases (MSE and MedAE). 
Table 5 - Some Statistics Obtained for the Second Simulation

Ind. Portfolio/Fund

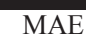

MSE

$\operatorname{MaxAE}$

MedAE

Fund 1

Fund 2

Fund 3

Source: Authors

\section{Net Assets (approx.)}

$R \$ 200$ million
$R \$ 200$ million
$R \$ 200$ million
$R \$ 200$ million
$R \$ 482$ million
R\$ 4 billion
$R \$ 118$ million

$\begin{gathered}\text { B-VaR } \\ \text { (95\%, 1 day) }\end{gathered}$
$-0.066 \%$
$-0.047 \%$
$-0.090 \%$
$-0.035 \%$
$-0.020 \%$
$-0.072 \%$
$-0.053 \%$

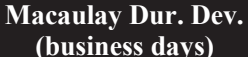

(business days)

-0.16
-1.68
0.87
-0.24
-80
-283
-53

Beta

(及)

$1.0530 \quad 98.45 \%$

$1.0513 \quad 98.99 \%$

$1.0548 \quad 96.90 \%$

$1.0326 \quad 99.45 \%$

$0.9629 \quad 99.91 \%$

$0.8321 \quad 99.99 \%$

0.9301

$98.10 \%$

The comments above are also valid when considering Figure 3 and Figure 2, which depict the deviations of the MD for each of the 126 scenarios used. It can also be observed in Figure 3 that for the stress scenarios, the maximum MD deviations (in absolute value, or modulus) rise from 6 business days in Figure 2 to 10 business days, also a result of the worse indexation obtained because of the greater constraints on investments imposed in model (11) by the smaller $c$.

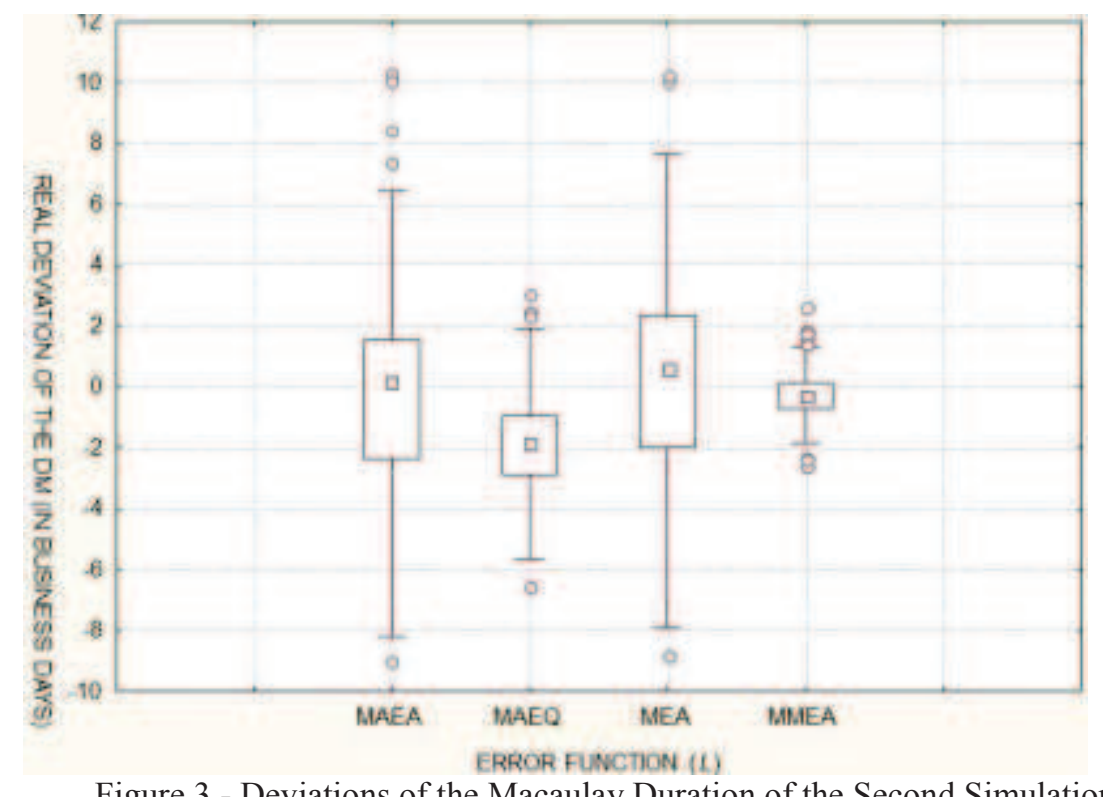

Figure 3 - Deviations of the Macaulay Duration of the Second Simulation

Finally, analysis of Figure 4 and Figure 1 reveals again the worse quality of the indexation in the case of the loss functions MAE and MaxAE. 


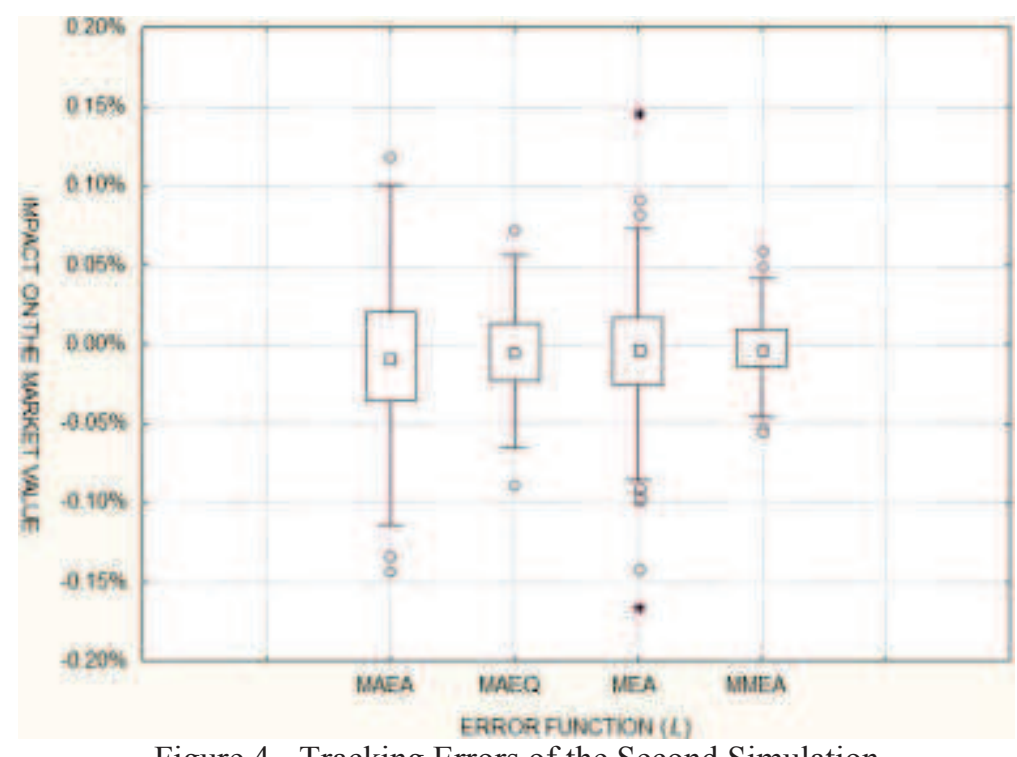

Figure 4 - Tracking Errors of the Second Simulation

\subsection{THIRD SIMULATED STUDY}

In this third simulation exercise, we raised the minimum retention of cash from $\alpha=1 \%$ to $\alpha=5 \%$, while keeping all the other parameters the same as in the first simulated study. The objective here is to illustrate the impact of greater cash reserve demand on the quality of the indexation obtained. It should be mentioned that this alteration can be considered usual in moments of greater volatility and/or less market liquidity, with the manager increasing the cash on hand to more easily meet redemption demands from clients.

Table 6 shows the allocations obtained for the four loss functions used.

\begin{tabular}{|c|c|c|c|c|c|c|c|c|c|}
\hline \multirow[t]{2}{*}{ Maturity } & \multirow[t]{2}{*}{ Weight } & \multicolumn{2}{|c|}{ MAE } & \multicolumn{2}{|l|}{ MSE } & \multicolumn{2}{|l|}{ MaxAE } & \multicolumn{2}{|c|}{ MedAE } \\
\hline & & Lots / Value & $\%$ & Lots / Value & $\%$ & Lots / Value & $\%$ & Lots / Value & $\%$ \\
\hline $15 / 05 / 2011$ & $10.10 \%$ & & & & & & & & \\
\hline $15 / 11 / 2011$ & $3.37 \%$ & & & & & & & & \\
\hline $15 / 08 / 2012$ & $9.61 \%$ & & & & & 1 & 5.03 & & \\
\hline $15 / 05 / 2013$ & $13.09 \%$ & 2 & 9.90 & 1 & 4.95 & & & 5 & 24.76 \\
\hline $15 / 08 / 2014$ & $3.63 \%$ & 1 & 5.01 & & & 1 & 5.01 & & \\
\hline $15 / 05 / 2015$ & $3.63 \%$ & 5 & 24.76 & 5 & 24.76 & 5 & 24.76 & 1 & 4.95 \\
\hline $15 / 08 / 2016$ & $0.26 \%$ & & & & & & & & \\
\hline $15 / 05 / 2017$ & $8.13 \%$ & 2 & 9.99 & 3 & 14.99 & 3 & 14.99 & 3 & 14.99 \\
\hline $15 / 08 / 2020$ & $5.19 \%$ & 2 & 10.17 & 2 & 10.17 & 2 & 10.17 & 1 & 5.08 \\
\hline $15 / 08 / 2024$ & $7.63 \%$ & 3 & 15.43 & 3 & 15.43 & 3 & 15.43 & 3 & 15.43 \\
\hline $15 / 08 / 2030$ & $1.01 \%$ & & & & & & & & \\
\hline $15 / 05 / 2035$ & $7.26 \%$ & & & & & 1 & 5.21 & 1 & 5.21 \\
\hline $15 / 08 / 2040$ & $1.34 \%$ & & & & & & & & \\
\hline $15 / 05 / 2045$ & $13.58 \%$ & 3 & 16.07 & 3 & 16.07 & 1 & 5.36 & 3 & 16.07 \\
\hline $15 / 08 / 2050$ & $3,12 \%$ & & & & & 1 & 5,40 & & \\
\hline Cash & & F $\$ 34,695.166$ & 8.67 & $\mathrm{R} \$ 54,564.744$ & 13.64 & $\mathrm{R} \$ 34,572.511$ & 8.64 & $\mathrm{R} \$ 54,058.499$ & 13.51 \\
\hline
\end{tabular}

Source: Authors.

Table 7 reports the statistics obtained that measure the quality of the final fit, which should be compared with the statistics in Table 3. Comparison of the tables reveals little change in the goodness of fit, with equivalent levels for B-VaR, for example. 
Table 7 - Some Statistics Obtained for the Third Simulation

\begin{tabular}{|c|c|c|c|c|c|}
\hline Ind. Portfolio/Fund & Net Assets (approx.) & $\begin{array}{c}\text { B-VaR } \\
(95 \%, 1 \text { day })\end{array}$ & $\begin{array}{l}\text { Macaulay Dur. Dev. } \\
\text { (business days) }\end{array}$ & $\begin{array}{l}\text { Beta } \\
(\beta)\end{array}$ & $32^{2 x}$ \\
\hline MAE & $\mathrm{R} \$ 400$ million & $-0.038 \%$ & -0.16 & 1.0440 & $99.40 \%$ \\
\hline MSE & $\mathrm{R} \$ 400$ million & $-0.043 \%$ & -1.35 & 1.0406 & $99.31 \%$ \\
\hline MaxAE & $\mathrm{R} \$ 400$ million & $-0.048 \%$ & 0.37 & 1.0519 & $99.92 \%$ \\
\hline MedAE & $\mathrm{R} \$ 400$ million & $-0.019 \%$ & -0.12 & 1.0131 & $99.82 \%$ \\
\hline Fund 1 & $\mathrm{R} \$ 482$ million & $-0.020 \%$ & -80 & 0.9629 & $99.91 \%$ \\
\hline Fund 2 & $\mathrm{R} \$ 4$ billion & $-0.072 \%$ & -283 & 0.8321 & $99.99 \%$ \\
\hline Fund 3 & $\mathrm{R} \$ 118$ million & $-0.053 \%$ & -53 & 0.9301 & $98.10 \%$ \\
\hline
\end{tabular}

Source: Authors

Figure 5 and Figure 6 should be considered together with Figure 1 and Figure 2. It can be observed that the order of magnitude of the deviations is maintained, with small alterations in the case of the loss function MedAE, but without this allowing establishing substantial differences between this and the first simulated study.

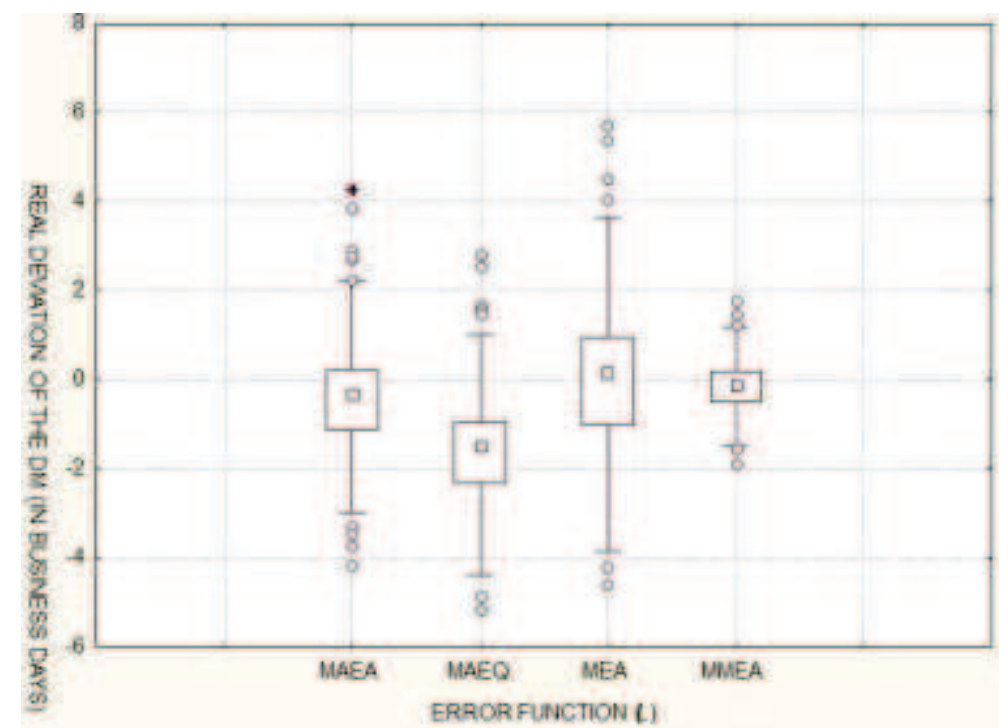

Figure 5 - Deviations of the Macaulay Duration of the Third Simulation

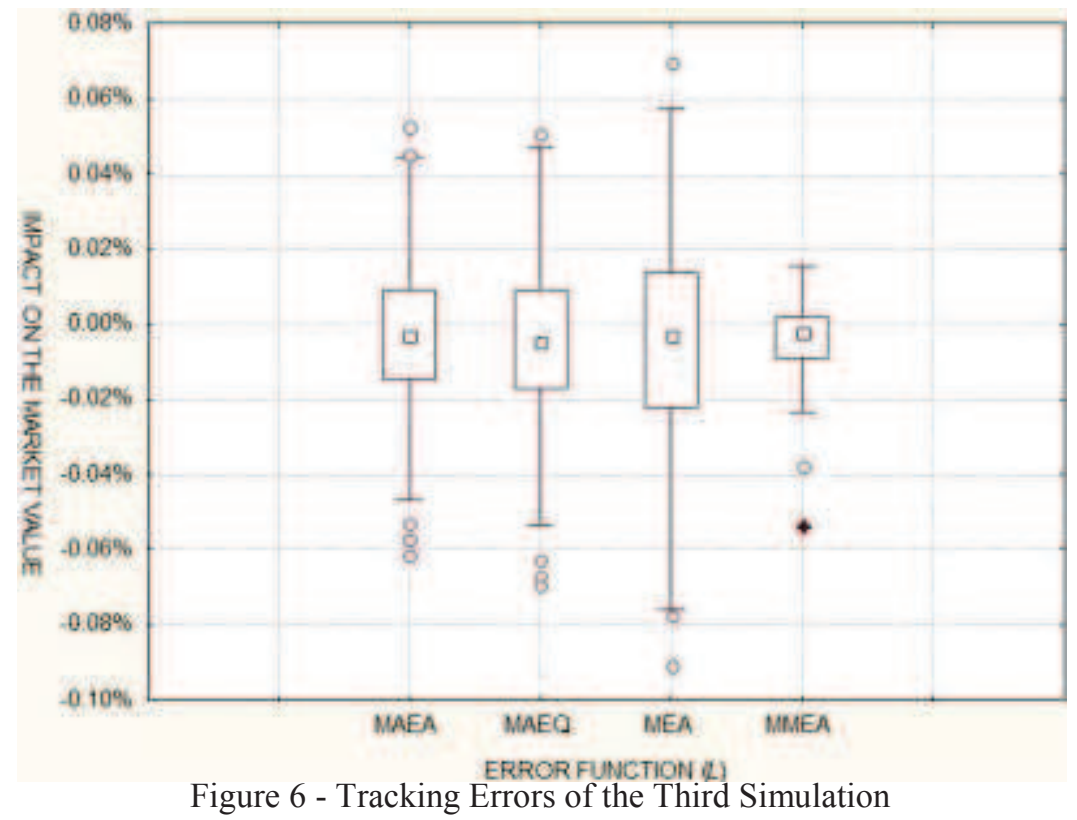




\subsection{FOURTH SIMULATED STUDY}

Here we considered the case of maximum allocation in each maturity by doubling the value of $\gamma$ from $0,2 \%$ to $0,4 \%$, while maintaining the total amount available for investment and minimum demand for cash at the same levels as in the first simulation exercise. The objective here is to investigate the impact of possible investment in larger numbers of lots (for each available maturity) on the final indexation.

Table 8 reports the allocations obtained for the four loss functions. Analysis of Table 8 against Table 2 illustrates a tendency for greater concentration of the indexed portfolios in intermediate maturities in this study for three of the loss functions (MAE, MSE and MaxAE).

Table 8 - Portfolios Indexed to the IMA-B of the Fourth Simulation

\begin{tabular}{|c|c|c|c|c|c|c|c|c|c|}
\hline \multirow[t]{2}{*}{ Maturity } & \multirow{2}{*}{ Weight } & \multicolumn{2}{|c|}{ MAE } & \multicolumn{2}{|l|}{ MSE } & \multicolumn{2}{|c|}{ MaxAE } & \multicolumn{2}{|c|}{ MedAE } \\
\hline & & Lots / Value & $\%$ & Lots / Value & $\%$ & Lots / Value & $\%$ & Lots / Value & $\%$ \\
\hline $15 / 05 / 2011$ & $10.10 \%$ & & & & & & & 1 & 5.00 \\
\hline $15 / 11 / 2011$ & $3.37 \%$ & & & & & & & & \\
\hline $15 / 08 / 2012$ & $9.61 \%$ & & & & & & & 3 & 15.10 \\
\hline $15 / 05 / 2013$ & $13.09 \%$ & & & & & & & & \\
\hline $15 / 08 / 2014$ & $3.63 \%$ & 1 & 5.01 & 1 & 5.01 & & & 2 & 10.02 \\
\hline $15 / 05 / 2015$ & $3.63 \%$ & 7 & 34.66 & 7 & 34.66 & 6 & 29.71 & 1 & 4.95 \\
\hline $15 / 08 / 2016$ & $0.26 \%$ & & & & & & & & \\
\hline $15 / 05 / 2017$ & $8.13 \%$ & 5 & 24.98 & 5 & 24.98 & 5 & 24.98 & 5 & 24.98 \\
\hline $15 / 08 / 2020$ & $5.19 \%$ & 2 & 10.17 & 2 & 10.17 & 1 & 5.08 & 1 & 5.08 \\
\hline $15 / 08 / 2024$ & $7.63 \%$ & 1 & 5.14 & 1 & 5.14 & 6 & 30.85 & 2 & 10.28 \\
\hline $15 / 08 / 2030$ & $1.01 \%$ & & & & & & & & \\
\hline $15 / 05 / 2035$ & $7.26 \%$ & & & & & & & 1 & 5.21 \\
\hline $15 / 08 / 2040$ & $1.34 \%$ & & & & & & & 1 & 5.34 \\
\hline $15 / 05 / 2045$ & $13.58 \%$ & 3 & 16.07 & 3 & 16.07 & & & 2 & 10.71 \\
\hline $15 / 08 / 2050$ & $3.12 \%$ & & & & & 1 & 5.40 & & \\
\hline Cash & & F $\$ 15,879.956$ & 3.97 & $\mathrm{R} \$ 15,879.956$ & 3.97 & $\mathrm{R} \$ 15,876.445$ & 3.97 & $\mathrm{R} \$ 13,248.170$ & 3.31 \\
\hline
\end{tabular}

Source: Authors.

Table 9 shows the goodness-of-fit statistics obtained, which should be considered together with Table 3. No relevant alterations can be observed in the quality of the indexation for the three loss functions considered.

Table 9 - Some Statistics Obtained for the Fourth Simulation

\begin{tabular}{|c|c|c|c|c|c|}
\hline Ind. Portfolio/Fund & Net Assets (approx.) & $\begin{array}{c}\text { B-VaR } \\
(95 \%, 1 \text { day })\end{array}$ & $\begin{array}{l}\text { Macaulay Dur. Dev. } \\
\text { (business days) }\end{array}$ & $\begin{array}{c}\text { Beta } \\
(\boldsymbol{\beta})\end{array}$ & $i^{2}{ }^{2}$ \\
\hline MAE & $\mathrm{R} \$ 400$ million & $-0.056 \%$ & -0.22 & 1.0711 & $98.58 \%$ \\
\hline MSE & $\mathrm{R} \$ 400$ million & $-0.056 \%$ & -0.22 & 1.0711 & $98.58 \%$ \\
\hline MaxAE & $\mathrm{R} \$ 400$ million & $-0.081 \%$ & +0.42 & 1.0853 & $97.02 \%$ \\
\hline MedAE & $\mathrm{R} \$ 400$ million & $-0.028 \%$ & -0.20 & 1.0289 & $99.58 \%$ \\
\hline Fund 1 & $\mathrm{R} \$ 482$ million & $-0.020 \%$ & -80 & 0.9629 & $99.91 \%$ \\
\hline Fund 2 & $\mathrm{R} \$ 4$ billion & $-0.072 \%$ & -283 & 0.8321 & $99.99 \%$ \\
\hline Fund 3 & R\$ 118 million & $-0.053 \%$ & -53 & 0.9301 & $98.10 \%$ \\
\hline
\end{tabular}

Source: Authors.

Figure 7 and Figure 8 present data that should be considered together with Figure 1 and Figure 2. Once again, no alterations are observed in the goodness of fit of the loss functions considered. 


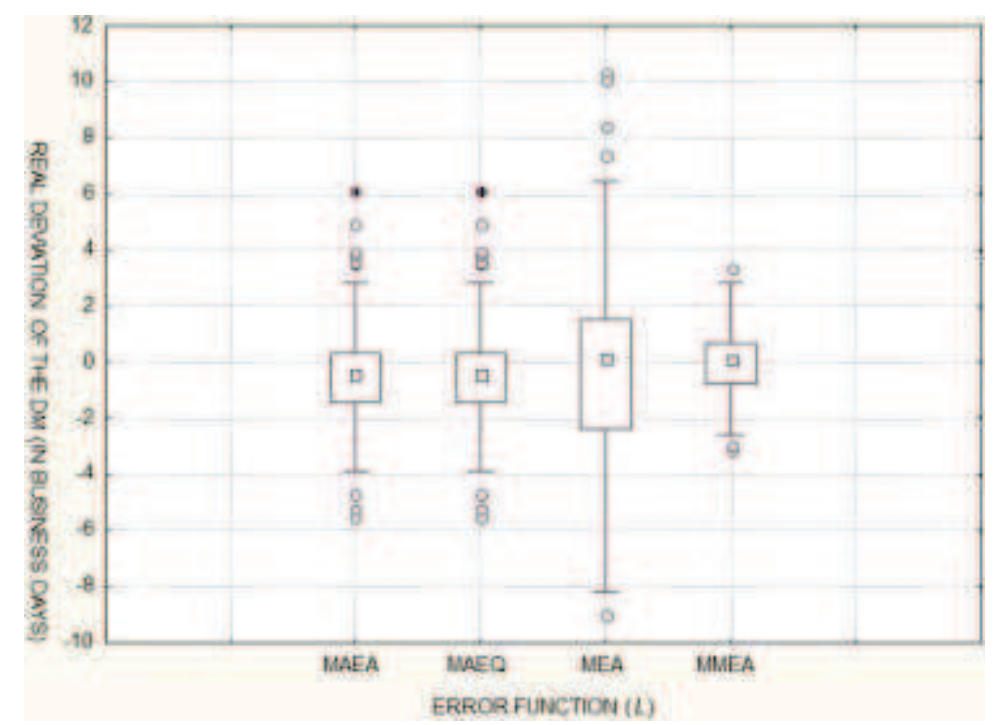

Figure 7 - Deviations of the Macaulay Duration of the Fourth Simulation

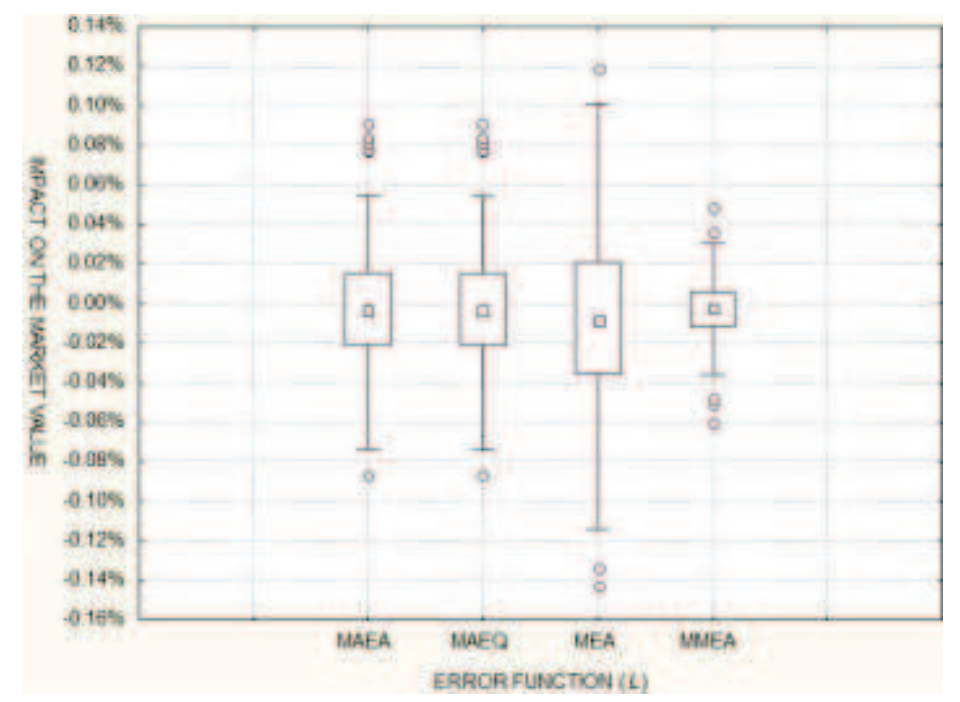

Figure 8 - Tracking Errors of the Fourth Simulation

\subsection{FIFTH SIMULATED STUDY}

In this fifth and last simulation exercise, we maintained the parameters $c, \alpha$ and $\gamma$ as in the first example, but changed the scenarios utilized: instead of using the variations for the IPCA term structure for the second half of 2010, now we use the variations for the first half of that year. The purpose is to illustrate the possible changes in the arrangement of the deviations between the indexed portfolio and the IMA-B for another set of historical scenarios.

The compositions of the indexed portfolios are given in Table 10 and their goodness-offit statistics are reported in Table 11. There are small alterations in the compositions and performance of the indexation. It is interesting to mention that in the first half of 2010, there were some days when greater than usual variations occurred in the IPCA term structure, but these did not substantially affect the goodness of fits, and for example, the B-VaR of the indexed portfolios. 
Table 10 - Portfolios Indexed to the IMA-B of the Fifth Simulation

\begin{tabular}{|c|c|c|c|c|c|c|c|c|c|}
\hline \multirow[t]{2}{*}{ Maturity } & \multirow[t]{2}{*}{ Weight } & \multicolumn{2}{|c|}{ MAE } & \multicolumn{2}{|l|}{ MSE } & \multicolumn{2}{|c|}{$\operatorname{MaxAE}$} & \multicolumn{2}{|c|}{ MedAE } \\
\hline & & Lots / Value & $\%$ & Lots / Value & $\%$ & Lots / Value & $\%$ & $\begin{array}{c}\text { Lots / Value } \\
2\end{array}$ & $\begin{array}{c}\% \\
10.01\end{array}$ \\
\hline $15 / 11 / 2011$ & $3.37 \%$ & & & & & & & & \\
\hline $15 / 08 / 2012$ & $9.61 \%$ & 2 & 10.07 & 1 & 5.03 & 1 & 5.03 & 1 & 5.03 \\
\hline $15 / 05 / 2013$ & $13.09 \%$ & 1 & 4.95 & 2 & 9.90 & 2 & 9.90 & 5 & 24.76 \\
\hline $15 / 08 / 2014$ & $3.63 \%$ & & & 1 & 5.01 & 1 & 5.01 & 1 & 5.01 \\
\hline $15 / 05 / 2015$ & $3.63 \%$ & 5 & 24.76 & 4 & 19.81 & 4 & 19.81 & & \\
\hline $15 / 08 / 2016$ & $0.26 \%$ & & & & & & & & \\
\hline $15 / 05 / 2017$ & $8.13 \%$ & 3 & 14.99 & 3 & 14.99 & 3 & 14.99 & 2 & 9.99 \\
\hline $15 / 08 / 2020$ & $5.19 \%$ & 2 & 10.17 & 2 & 10.17 & 2 & 10.17 & & \\
\hline $15 / 08 / 2024$ & $7.63 \%$ & 3 & 15.43 & 3 & 15.43 & 3 & 15.43 & 3 & 15.43 \\
\hline $15 / 08 / 2030$ & $1.01 \%$ & & & & & & & & \\
\hline $15 / 05 / 2035$ & $7.26 \%$ & 1 & 5.21 & 1 & 5.21 & 1 & 5.21 & 3 & 15.64 \\
\hline $15 / 08 / 2040$ & $1.34 \%$ & & & & & & & & \\
\hline $15 / 05 / 2045$ & $13.58 \%$ & 2 & 10.71 & 2 & 10.71 & 2 & 10.71 & 2 & 10.71 \\
\hline $15 / 08 / 2050$ & $3.12 \%$ & & & & & & & & \\
\hline Cash & & $\mathrm{R} \$ 14,861.667$ & 3.72 & $\mathrm{R} \$ 14,954.872$ & 3.74 & $\mathrm{R} \$ 14,954.872$ & 3.97 & $\mathrm{R} \$ 13,686.735$ & 3.42 \\
\hline
\end{tabular}

Source: Authors.

Table 11 - Some Statistics Obtained for the Fifth Simulation

\begin{tabular}{|c|c|c|c|c|c|}
\hline Ind. Portfolio/Fund & Net Assets (approx.) & $\begin{array}{c}\text { B-VaR } \\
(95 \%, 1 \text { day })\end{array}$ & $\begin{array}{c}\text { Macaulay Dur. } \\
\text { Dev. } \\
\text { (business days) }\end{array}$ & $\begin{array}{c}\text { Beta } \\
\text { ( } \beta \text { ) }\end{array}$ & $\mathrm{s}^{2 / 2}$ \\
\hline MAE & $\mathrm{R} \$ 400$ million & $-0.038 \%$ & -0.98 & 1.0564 & $98.65 \%$ \\
\hline MaxAE & $\mathrm{R} \$ 400$ million & $-0.038 \%$ & -0.35 & 1.0568 & $98.65 \%$ \\
\hline MedAE & $\mathrm{R} \$ 400$ million & $-0.023 \%$ & -0.89 & 0.9960 & $99.52 \%$ \\
\hline Fund 1 & $\mathrm{R} \$ 482$ million & $-0.020 \%$ & -80 & 0.9629 & $99.91 \%$ \\
\hline Fund 2 & R\$ 4 billion & $-0.072 \%$ & -283 & 0.8321 & $99.99 \%$ \\
\hline
\end{tabular}

Source: Authors.

The tracking errors and deviations of the MD of this new simulation study are shown in Figure 9 and Figure 10, respectively. Analysis of these two figures and their comparison with Figure 1 and Figure 2 clearly show outliers (represented in the box-plots with “*”), something not observed in any other figure so far. Even with these outliers, the fit remained good, especially when comparing the results obtained for the three funds offered to the Brazilian financial market according to Table 11.

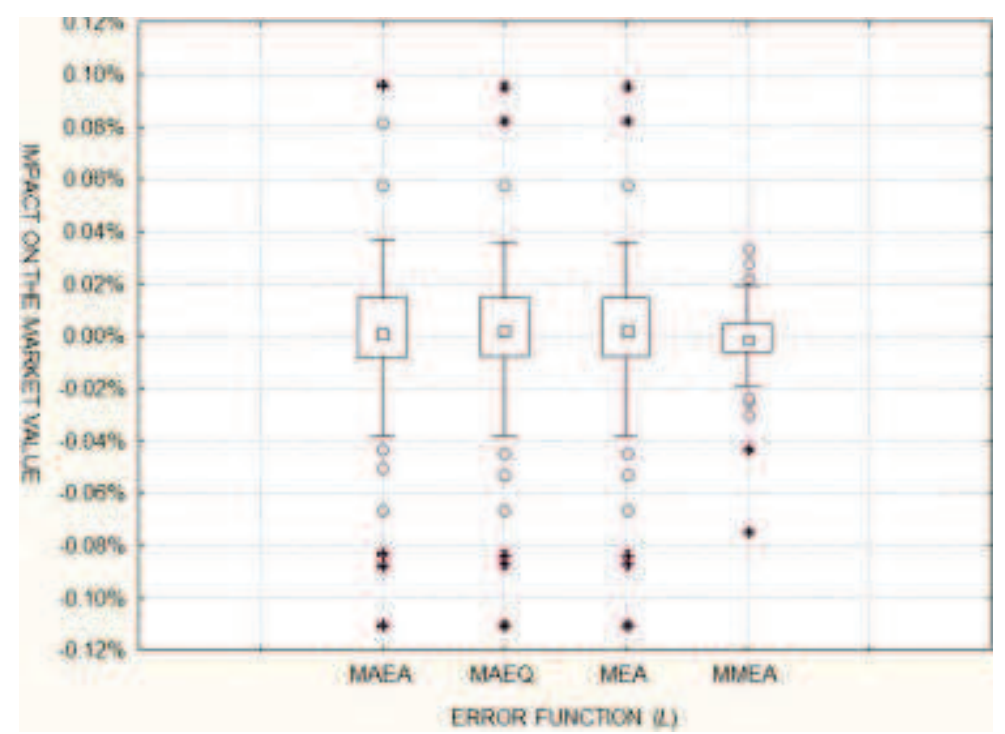

Figure 9 - Tracking Errors of the Fifth Simulation 


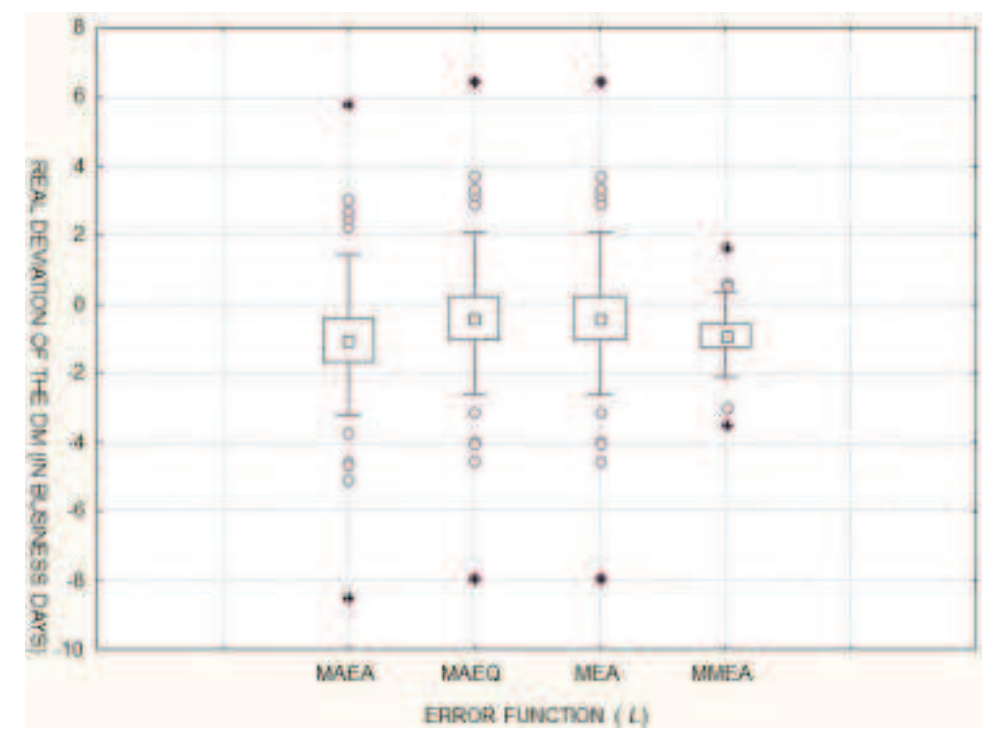

Figure 10 - Deviations of the Macaulay Duration of the Fifth Simulation

\section{CONCLUSIONS}

In this article we considered the problem of indexing investment portfolios to the IMAB, a Brazilian fixed-income index. Because of the transformations in the country's fixedincome market in the past decade - longer maturity of federal debt issues, changes in the benchmark indexes for monitoring investments, increase in assets managed by private pension funds, tendency for lower long-term interest rates and growth of the bond market - there is growing interest of fund managers (investment and pension funds) in long-term bonds indexed to the consumer price index (IPCA), such as the NTN-Bs.

Passive management of assets has gained greater acceptance in Brazil and abroad, especially in the case of pension funds. Among the possibilities for passive management of assets in the fixed-income market is regular balancing of a portfolio to continually adjust it to changes in the benchmark index - maturities, composition, payment of interest or amortization of principal and differentiated returns of assets.

The method was described and illustrated numerically through five simulation exercises. The proposal is based on a set of scenarios to represent the possible movements in the IPCA term structure, allowing marking the NTN-Bs to the market for each scenario, and hence defining different levels of return and risk for each asset over the horizon for restructuring the portfolio chosen by the manager. Therefore, once the parameters of a tracking error optimization model and the loss function are chosen by the manager, the number of assets of each maturity to be bought/sold can be obtained for each step of the balancing. 
The results obtained from the simulation studies with real data from the federal bond market indicate that the tracking errors were well controlled when compared with the results obtained for the three largest investment funds indexed to the IMA-B offered to the public market in Brazil. The impacts of changes in the input parameters on the probability distribution of the deviations were considered and illustrated with real data.

This article makes a contribution to the passive management of fixed-income portfolios in Brazil. Since the proposal enables better control of the tracking errors of indexed portfolios, it should facilitate the passive management of assets in the local fixed-income market. In particular, the method can be directly applied to build exchange-traded funds tied to the IMAB.

A limitation of this article is that there are other fixed-income indexes, like the IRF-M, IMA-General and IMA-C, that can be chosen to index fixed-income portfolios in Brazil. We limited our analysis to the IMA-B. Therefore, a possible extension for the proposed method is its adaptation for indexing to the IRF-M, when LTNs and NTN-Fs must be used to structure the portfolio. Another possible extension is adaptation of the method to indexes of corporate bond debt, where credit risk is also present.

Another interesting extension of this work would be incorporation of the proposed method in a dynamic strategy that alternates between active and passive management, as in the case of enhanced-indexing, which is just starting to be used by investment and pension fund managers in Brazil.

\section{REFERENCES}

ALEXANDER, C.; BARBOSA, A. Hedging index exchange-traded funds. Journal of Banking \& Finance, v. 32, n. 1, p. 326-337, 2008.

AMENC, N.; GOLTZ, F. The way ahead for exchange-traded funds: results from a European survey. The Journal of Alternative Investments, v. 12, n. 2, p.50-64, 2009.

ANBIMA. A importância dos índices ANBIMA para os investidores institucionais e o desenvolvimento de novos benchmakrs. In: ANAIS DO CONGRESSO BRASILEIRO DOS FUNDOS DE PENSÃO: PROSPERIDADE E DESAFIOS, 30., 2010, Olinda (PE). Anais... Olinda: ANBIMA, 2010a.

. Mercado de renda fixa. Relatório Técnico, ANBIMA, Rio de Janeiro, 2010b. Mercado de renda fixa. Relatório Técnico, ANBIMA, Rio de Janeiro, 2014.

ANDIMA. IMA completa quatro anos como novo parâmetro para o mercado de renda fixa. Relatório Técnico, Rio de Janeiro: ANDIMA, 2009. 
BANCO DO BRASIL. Nota técnica MODERF n 2006/003. Relatório Técnico (Interno). Rio de Janeiro: Banco do Brasil, 2006.

Manual corporativo de marcação a mercado. Relatório Técnico (Interno). Rio de Janeiro: Banco do Brasil, 2010.

BARRO, D.; CANESTRELLI, E. Tracking error: a multistage portfolio model. Annals of Operations Research, v. 165, n. 1, 47-66, 2009.

BLACKROCK. Investindo em fundos de índices (ETFs): O Melhor de Dois Mundos. In: ANAIS DO BRAZIL EQUITY IDEAS CONFERENCE, 6., 2013, São Paulo (SP). Anais... São Paulo: BEIC, 2013.

BLITZ, D.; HUIJ, J.; SWINKELS, L. The performance of European index funds and exchange-traded funds. European Financial Management, v. 18, n. 2, p. 649-662, 2012.

BM\&FBOVESPA. Boletim ETF: dezembro de 2012. Relatório Técnico, BM\&FBOVESPA, São Paulo, 2013.

BNDES. Sala de imprensa 2004. Disponível em:

$<$ http://www.bndes.gov.br/SiteBNDES/bndes/bndes_pt/Institucional/Sala_de_Imprensa/Notic ias/2004/20040706_not841.html>. Acesso em: 09 dez. 2013.

BRASIL. Relatório mensal da dívida pública: dezembro. Brasília: Secretaria do Tesouro Nacional, 2009

Relatório mensal da dívida pública: dezembro. Brasília: Secretaria do Tesouro Nacional, 2013.

BRUCE, B. Exchange traded funds. New York: Institutional Investor Journal, 2009.

BRUCE, B.; FUHR, D. (Eds.). ETFs \& indexing in European markets. New York: Institutional Investor Journal, 2012.

BUCKLEY, I. R. C; KORN, R. Optimal index tracking under transaction costs and impulse control. International Journal of Theoretical and Applied Finance, v. 1, n. 3, 315-330, 1998.

CALDEIRA, J. F.; PORTUGAL, M. Estratégia long-short neutra ao mercado e index tracking baseadas em portfólios cointegrados. Revista Brasileira de Finanças, v. 8, n. 4, 469-504, 2010.

CANAKGOZ, N. A.; BEASLEY, J. E. Mixed-integer programming approaches for index tracking and enhanced indexation. European Journal of Operational Research, v. 196, n. 2, 384-399, 2009.

CARVALHO, L. O.; MORAIS, J. F. M. Mercado primário da dívida pública federal. In: SILVA, A. C.; CARVALHO, L. O.; MEDEIROS, O. L. (Orgs.). Dívida pública: a experiência brasileira. Brasília: Secretaria do Tesouro Nacional, p. 359-381, 2009.

CFA INSTITUTE. Corporate finance and portfolio management. New Jersey: Wiley, 2009. 
COLEMAN, T. F.; LI, Y.; HENNIGER, J. Minimizing tracking error while restricting the number of assets. Journal of Risk, v. 8, n. 1, 33-56, 2006.

CORNUEJOLS, G; TUTUNCU, R. Optimization methods in finance. Cambridge: Cambridge University Press, 2007.

CREMERS, K. J. M.; PETAJISTO, A. How active is your fund manager? A new measure that predicts performance. The Review of Financial Studies, v. 22, n. 9, p. 3329-3365, 2009.

DUARTE, A. M. Indexing stock portfolios in Brazil: tracking the Ibovespa and the FGV100. Emerging Markets Quarterly, v. 1, n. 1, p. 20-26, 1997.

DUARTE, A. M. Gestão de riscos: fundos de investimentos. São Paulo: Pearson, 2005.

FABOZZI, F.J. Duration, convexity, and other bond risk measures. New Hope: Frank J. Fabozzi Associates, 1999.

FABOZZI, F. J.; MARKOWITZ, H. The theory and practice of investment management. New Jersey: Wiley, 2011.

FAMA, E; FRENCH, K. Luck versus skill in the cross-section of mutual fund returns. The Journal of Finance, v. 65, n. 5, 1915-1947, 2010.

FERRI, R. A. All about index funds. New York: McGraw-Hill, 2007.

FRINO, A.; GALLAGHER, D. R. Tracking S\&P500 index funds. Journal of Porfolio Management, v. 28, n. 1, 44-55, 2001.

FUSCO, R. A. et al. Quantitative investment analysis. New Jersey: Wiley, 2007.

GAIVORONSKI, A. A.; KRYLOV, S.; VAN DER WIJST, N. Optimal portfolio selection and dynamic benchmark tracking. European Journal of Operational Research, v. 163, n. 1, p. 115-131, 2005.

GUASTAROBA, G.; SPERANZA, M. G. Kernel search: an application to the index tracking problem. European Journal of Operational Research, v. 217, n. 1, 54-68, 2012.

HARPER, J.; MADURA, J.; SCHUNUSENBERG, O. Performance comparison between exchange-traded funds and closed-end country funds. Journal of International Financial Markets, Institutions and Money, v. 16, n. 2, p. 104-122, 2006.

INVESTMENT COMPANY INSTITUTE. Investment company fact book: a review of trends and activity in the investment company industry. Technical Report, Investment Company Institute, Washington, 2011.

Investment company fact book: a review of trends and activity in the investment company industry. Technical Report, Investment Company Institute, Washington, 2013.

JANSEN, R.; VAN DIJK, R. Optimal benchmark tracking with small portfolios. Journal of Portfolio Management, v. 29, n. 1, p. 33-39, 2002. 
JORION, P. Value-at-risk: the new benchmark for managing investment risk. New York: McGraw-Hill, 2006.

KOSTOVETSKY, L. Index mutual funds and exchange traded funds: a comparison of two methods of passive investment. The Journal of Porfolio Management, v. 21, n. 1, p. 80-92, 2003.

KRINK, T.; MITTNIK, S.; PATERLINI, S. Differential evolution and combinatorial search for constrained index-tracking. Annals of Operations Research, v. 172, n. 3, 153-176, 2009.

LARSEN, G. A.; RESNICK, B. G. Empirical insights on indexing. The Journal of Portfolio Management, v. 25, n. 1, 51-60, 1998.

MARGIN, J. L. et al. Managing investment portfolios: a dynamic approach. New Jersey: Wiley, 2007.

MATOS, G. A. S.; IQUIAPAZA, R. A.; FERREIRA, B. P. Análise da exposição a perdas dos ETFs brasileiros conforme as técnicas de avaliação de risco de mercado Value-at-Risk (VaR) e Expected Shortfall (ES). Brazilian Business Review, v. 11. n. 4, 91-115, 2014.

PETAJiSTO, A. The index premium and its hidden cost in tracking error. The Journal of Empirical Finance, v. 18, n. 2, 271-288, 2011.

REILLY, F. K.; KAO, G. W. Alternative bond market indexes. Financial Analysts Journal, v. 48, n. 1, p. 44-58, 1992.

ROMPOTIS, G. Interfamily competition on index tracking: the case of the Vanguard ETFs and index funds. Journal of Asset Management, v. 10, n. 1, p. 263-278, 2009.

SANFINS, M. A. R. B.; DUARTE, A. M. Indexação de fundos de pensão com fundos de índice. Revista Brasileira de Finanças, v. 12, n. 2, p. 13-39, 2014.

SANT'ANNA, L. R.; FILOMENA, T. P.; BORENSTEIN, D. Index Tracking com controle do número de ativos. Revista Brasileira de Finanças, v. 12, n. 1, p. 89-119, 2014.

SAMUEL, S. L. Queda dos juros amplia importância de referências. Revista Fonte, v. 4, p. 4-5, 2009.

SILVA, A. C.; CARVALHO, L. O.; GARRIDO, F. E. Evolução recente do mercado de títulos da dívida pública federal. In: SILVA, A. C.; CARVALHO, L. O.; MEDEIROS, O. L. (Orgs.). Dívida pública: a experiência brasileira. Brasília: Secretaria do Tesouro Nacional, 2009.

TAHA, H. A. Pesquisa operacional. São Paulo: Prentice Hall, 2008.

VOLPERT, K. E. Chapter 4: Managing index and enhanced indexed bond portfolios. In: FABOZZI, F. J. (Eds.). Fixed income readings for the chartered financial analysts program. New Hope: Frank J. Fabozzi Associates, 2000.

YAO, D. D.; ZHANG, S.; ZHOU, X. Y. Tracking a financial benchmark using a few assets. Operations Research, v. 54, n. 4, p. 232-246, 2006. 